\title{
A Felső-kiskunsági záródó homokpusztagyepek (Festucetum wagneri) természetvédelmi szempontból kitüntetett jelentőségü növényfajainak termőhelyi jellemzése
}

\author{
Fülöp Bence ${ }^{1}$, Nyári László ${ }^{1}$, Deák Márk ${ }^{1}$, Balogh Annamária ${ }^{1}$, \\ Molnár Csaba ${ }^{1}$, Bódis Judit ${ }^{1}$, Sisák István ${ }^{2}$ és Vadász Csaba ${ }^{3}$ \\ ${ }^{1}$ Pannon Egyetem, Georgikon Kar, 8360 Keszthely, Deák F. u. 16. \\ ${ }^{2}$ Szegedi Tudományegyetem, Mezögazdasági Kar, \\ 6800 Hódmezővásárhely Andrássy út 15. \\ ${ }^{3}$ Kiskunsági Nemzeti Park Igazgatóság, \\ 6000 Kecskemét, Liszt Ferenc u. 19.
}

E-mail:9112bence@gmail.com

\begin{abstract}
Összefoglaló: A homoki termőhelyeken a növényzet fajösszetételének és abundanciaviszonyainak meghatározásában a termőhelyi jellemzők kiemelt jelentőséggel bírnak. A záródó homokpusztagyepek (Festucetum wagneri) finom léptékủ mintázatainak megismeréshez jó alapot nyújthat, ha az ösgyepek fajkészletének termőhelyi igényeit meghatározzuk. Vizsgálataink során $208 \mathrm{db}$, egyenként 50x50 cm-es kvadrátban cönológiai felvételt készítettünk, majd a két legfelső talajszint megmintázásával összesen 416 talajmintát gyüjtöttünk. Meghatároztuk a talajminták mész- és humusztartalmát, szemcseméret összetételét és színmeghatározást is végeztünk. A statisztikai elemzések során varianciaanalízist és fơkomponens analízist használtunk. A vizsgálatok eredményei egyrészt rámutatnak egy, az edafikus tényezők szerinti finom, de határozottan kirajzolódó niche szegregációra, másrészt lehetővé teszik a jövőbeli élöhely-rekonstrukciók során az edafikus viszonyoknak megfelelő termőhely-specifikus fajkészlet kiválasztását és alkalmazását.
\end{abstract}

Kulcsszavak: Festucetum wagneri, edafikus tényezök, finom léptékủ mintázatok

\section{Bevezetés}

A homoki termőhelyek vegetációjának kialakulásában különösen nagy jelentőséggel bírnak a mikroléptékü termőhelyi különbségek. A homok humusztartalma és szemcseösszetétele erősen befolyásolja a növények által felvehető tápanyagtartalmat és az elérhető víz mennyiségét (Stefanovits 1981). A differenciált mikrodomborzatú kiskunsági tájban viszonylag kis távolságon belül is jelentősen 
eltérő mikroélőhelyek alakulhatnak ki (Molnár 2003, Molnár et al. 2006, Máté 2014).

A Pannon homoki gyepek (Natura 2000 kód: 6260) közösségi jelentőségú élőhelyek, amelyek kizárólag a Pannon biogeográfiai régióban fordulnak elő. A Pannon homoki gyepek napjainkban potenciális kiterjedésüknek csupán töredékén vannak jelen, ezeknek is csak az egyharmada mondható természetközeli állapotúnak (Máté 2014). A Duna-Tisza közén a zárt homoki sztyepprétek és a nyílt homoki gyepek jellemzőek. Ez utóbbiak közé tartoznak a félsivatagi jellegü, Festuca vaginata dominálta évelö nyílt homokpusztagyepek és a Festuca wagneri dominanciájával jellemezhető záródó homokpusztagyepek (Fekete et al. 2002). A Festucetum wagneri egy kevéssé kutatott társulás, amelynek több karakterisztikus faja is természetvédelmi oltalom alá esik.

A homoki gyepekre korábban a mezőgazdasági müvelésbe vonás és az erdősítés (ültetvénnyé alakítás) jelentette a legnagyobb veszélyt (Biró et al. 2011), napjainkban pedig a klímaváltozás (Molnár et al. 2018) és az inváziós fajok (Vadász 2015) térhódítása reprezentálja a legjelentősebb veszélyeztető tényezőket.

Az utóbbi évtizedekben a Kiskunsági Nemzeti Parkban nagy területen (kb. 2000 ha-on) hagytak fel szántókat gazdasági megfontolásból (Molnár et al. 2018), illetve természetvédelmi célból (Vadász 2015). Az ennek során létrejött nagy kiterjedésü parlagok szukcessziója meglehetősen lassú folyamat: az eddigi tapasztalatok alapján a legszárazabb termőhelyek vegetációja regenerálódik a leglassabban, amit a táji környezet, a forráspopulációktól való távolság és a területhasznosítási rendszer is befolyásol (Vadász Cs. személyes tapasztalata). A Kiskunsági Nemzeti Park Igazgatóság szakemberei ezt a folyamatot szeretnék segíteni azzal, hogy az adott terület termőhelyi viszonyainak megfelelő, rossz terjedőképességü, specialista edényes növényfajokat betelepítik e parlagokra (leggyakrabban magvetéssel), így segítve fajokban gazdag gyepek kialakulását.

A nagy fajgazdagságú ősgyepek fajkészletének és a vegetáció finom léptékü mintázatainak termőhelyi jellemzők általi befolyásoltságának kutatásával reményeink szerint olyan adatokat tudunk szolgáltatni, amelyek segíthetik a restaurációs munkák eredményességét is. Vizsgálataink során arra voltunk kíváncsiak, hogy 1) a záródó homokpusztagyeppel borított mintaterületek között mely talajtulajdonságok alapján mutatható ki különbség; 2) melyek az előforduló, természetvédelmi oltalomban részesülő fajok termőhelyeinek talajtani jellemzői; 3 ) melyek az egyes védett fajok elterjedését meghatározó legfontosabb talajtani tényezők. Közleményünk elsődleges célja, hogy alapadatokat biztosítsunk a jövőbeli természetvédelmi célú rekonstrukciós tevékenységekhez. 


\section{Módszerek}

A vizsgált terület két kistáj, a Csepeli-sík és a Kiskunsági-homokhát határán található.

A Csepeli-sík, mint kistáj talajtani szempontból nagyon változatos. Mozaikosságát mutatja, hogy egyetlen talajtípus sem borítja az összterület $20 \%$-át. A táj területén 5\%-nál kisebb kiterjedésben találhatóak meg a futóhomok és a mészlepedékes csernozjom talajok (Dövényi 2010). A jelentősen átalakított mezőgazdasági tájban kb. 20\%-nyi a természetes és féltermészetes növényzet borítása. Mivel nagyon változatos élőhelyek találhatóak itt, a flóra rendkívül diverz (Gergely et al. 2008).

A Kiskunsági-homokhát talajainak többsége homok jellegü. Területének 39\%át futóhomok teszi ki, a humuszos homoktalajok 17\%-ot foglalnak el (Dövényi 2010). A kistáj természetes növényzete gyakran izolált fragmentumokra korlátozódik, mégis - a napjainkra is fennmaradt ősgyepek és a természetközeli erdőssztyepp mozaikok miatt - az Alföld egyik legfajgazdagabb területe. Növényvilága endemizmusokban gazdag, a gyepek nagy részét extenzíven használják (Vidéki et al. 2008).

Mintaterületeinket a Peszéri-erdő és a Felső-kiskunsági turjánvidék kiemelt jelentőségü természetmegőrzési területek fajgazdag tisztásain és ősgyepjein (bolygatatlan talajú elsődleges gyepeken) jelöltük ki.

A terepi vizsgálatokat 2017. július 4-7. és 2018. június 30. - július 2. között végeztük, amely cönológiai felvételezésből és talajmintavételezésből állt. Hét különböző mintaterületen (1. táblázat) változó hosszúságú transzekteket (4-40 m)

1. táblázat: A mintaterületek jellemzői.

\begin{tabular}{|c|c|c|c|c|c|}
\hline Rövidítés & Mintaterület neve & $\begin{array}{l}\text { Transzektek } \\
\text { száma (db) }\end{array}$ & $\begin{array}{l}\text { Transzektek } \\
\text { hossza (m) }\end{array}$ & $\begin{array}{c}\text { Kvadrátok } \\
\text { száma összesen } \\
\text { (db) }\end{array}$ & $\begin{array}{c}\text { Hely } \\
\text { azonosító } \\
\text { (ID) }\end{array}$ \\
\hline FH & $\begin{array}{c}\text { Felső-peszéri } \\
\text { külső (honvédségi) } \\
\text { területek }\end{array}$ & 4 & $18,5,7,4$ & 38 & 1 \\
\hline $\mathrm{HHH}$ & Hármashatár-hegy & 5 & $4,4,4,4,4$ & 25 & 2 \\
\hline $\mathrm{Rh}$ & Rácház & 5 & $7,6,10,12,13$ & 53 & 3 \\
\hline $4 \mathrm{D}$ & $\begin{array}{l}\text { Peszéri-erdő 4D } \\
\text { erdőrészlete }\end{array}$ & 1 & 12 & 13 & 4 \\
\hline $7 \mathrm{I}$ & $\begin{array}{l}\text { Peszéri-erdő 7I } \\
\text { erdőrészlete }\end{array}$ & 1 & 40 & 41 & 5 \\
\hline ÖNy & Ösnyíres & 1 & 19 & 20 & 6 \\
\hline $\operatorname{Rez}$ & Rezervátum-tisztás & 1 & 17 & 18 & 7 \\
\hline
\end{tabular}


jelöltünk ki. A transzektek méretét a záródó homokpusztagyep (Festucetum wagneri) foltok mérete határozta meg.

A transzektek mentén 1 méterenként 50x50 cm-es kvadrátokat jelöltünk ki, összesen 204 db-ot, melyekben feljegyeztük a kvadrátban előforduló védett és fokozottan védett fajokat. Ezt követöen a kvadrát geometriai közepében (vagy az ahhoz legközelebbi olyan helyen, ahol nem volt védett növény) kézi talajfúróval furatot készítettünk. Minden esetben a felső két talajszint került megmintázásra. A felső szint: a humuszban gazdag felszíni réteg; alsó szint: a humuszos szint alatt található, színe alapján jól elkülönülő alsó réteg. Mindkét szint vastagságát centiméter pontossággal, mérőszalaggal mértük meg. A talajvizsgálat légszáraz mintákból száraz szitálással elkülönített hét szemcseméret frakció mérését, mésztartalom meghatározást, nedves és száraz talajon végzett színmeghatározást, valamint csak a felszíni réteg esetében humusztartalom meghatározást (Várallyay 1993) foglalt magába.

A szemcseösszetétel meghatározáshoz rázógépet használtunk és szitasorozattal az alábbi frakciókat különítettünk el: $>2 \mathrm{~mm} ; 1-2 \mathrm{~mm} ; 0,5-1 \mathrm{~mm} ; 0,25-0,5 \mathrm{~mm}$; $0,125-0,25 \mathrm{~mm} ; 0,056-0,125 \mathrm{~mm} ;<0,056 \mathrm{~mm}$. A légszáraz talajmintákból 100100 grammot mértünk ki. A rázatást minden esetben 5 percig folytattuk, a visszamérést táramérlegen végeztük. A talajokon a szerves anyag meghatározásához a Tyurin-féle módszert alkalmaztuk (Hargitai 1988). A színmérést egy HunterLab MiniScan XE Plus színmérő készülékkel végeztük el légszáraz és nedves állapotban.

Az adatelemzésekbe azokat a védett és fokozottan védett növényfajokat vontuk be, amelyek legalább 5 kvadrátban elöfordultak. Ez összesen 14 fajt érintett. Az értékeléshez ökológiai mutatószámokat használtunk. Az ökológiai jelzőszámok olyan értékszámok, amelyek elsősorban a fajok ökológiai magatartását jelzik. Ezek az értékszámok megmutatják az adott faj külső tényezőkkel való reakcióját. Mivel a besorolás szubjektív, csak terepi tapasztalatok alapján levont következtetéseken alapszik, ezért önmagában nem alkalmas ökológiai jellemzésre, viszont összehasonlító vizsgálatokra megfelelö (Czóbel et al. 2007). A nedvesség igényt [WZ (Zólyomi, skála: 0-11), FS (Soó, skála: 0-5), WB (Borhidi, skála: 1-12)]; és a talajreakciót [RZ (Zólyomi skála: 0-5), RS (Soó skála: 0-5), RB (Borhidi skála: 0-9)] vontuk be az értékelésbe (Horváth et al. 1995).

A statisztikai elemzésekhez az SPSS 21.0 programot használtuk (IBM SPSS, 2012). Az összes átlag összehasonlítására egytényezős varianciaanalízist (Oneway ANOVA), majd az átlagok páronkénti összehasonlítására (post hoc próbaként) Tukey-tesztet használtunk.

Főkomponens analízist végeztünk az egyes védett növényfajok elöfordulását legnagyobb mértékben befolyásoló talajtani paraméterek felhasználásával. 


\section{Eredmények}

A mintavételi egységekben összesen 108 edényes növényfaj egyedei fordultak elő, köztük 16 természetvédelmi oltalom alatt álló faj előfordulásait rögzítettük (2. táblázat). Leggyakrabban - összesen 128 kvadrátban - a Festuca wagneri egyedei kerültek elö, de magas volt a Stipa borysthenica és az Ephedra distachya előfordulások száma is.

2. táblázat: Az előforduló védett és fokozottan védett(*) növényfajok és előfordulásaik száma.

\begin{tabular}{cccc}
\hline Védett növényfaj & Elöfordulások száma & Védett növényfaj & Elöfordulások száma \\
\hline Festuca wagneri & 128 & Dianthus serotinus & 14 \\
Stipa borysthenica & 118 & Centaurea sadleriana & 13 \\
Ephedra distachya* & 107 & Alkanna tinctoria & 11 \\
Achillea ochroleuca & 50 & Allium & 5 \\
Gypsophila arenaria & 48 & sphaerocephalon & \\
Iris arenaria & 30 & Iris variegata & 5 \\
Centaurea arenaria & 17 & Anthericum liliago & 5 \\
Stipa pennata & 15 & Onosma & 2 \\
\hline
\end{tabular}

\section{Mintavételi helyek összehasonlitása}

A mintavételi helyek a humusz- és mésztartalom, valamint az 1-2 mm közötti frakció aránya alapján is erősen különböztek egymástól (3. táblázat). A humusztartalom alapján két csoport jött létre, a 4D erdőrészletben felvett lineákban szignifikánsan magasabb humusztartalmat mérünk, mint a többi - egymáshoz hasonló - helyen. Az 1-2 mm közötti talajfrakció alapján három csoport jött létre. A leg-

3. táblázat: Az egyes mintavételi helyeken vett, felső szintben mért talajtani paraméterek átlagértékei és szórásai. Az átlagértékek indexeiben szereplő betüjelzések a Tukey-teszt eredményét mutatják.

\begin{tabular}{ccccc}
\hline $\begin{array}{c}\text { Mintavételi } \\
\text { hely }\end{array}$ & Furat szám $(\mathrm{db})$ & $\begin{array}{c}\text { Humusztartalom } \\
(\%)\end{array}$ & $\begin{array}{c}1-2 \mathrm{~mm} \mathrm{közötti} \\
\text { frakció }(\mathrm{m} / \mathrm{m} \%)\end{array}$ & $\begin{array}{c}\text { Mésztartalom } \\
(\mathrm{m} / \mathrm{m} \%)\end{array}$ \\
\hline 4D & 13 & $2,57 \pm 1,29^{\mathrm{b}}$ & $2,08 \pm 0,76^{\mathrm{c}}$ & $0,59 \pm 0,58^{\mathrm{a}}$ \\
7I & 41 & $1,72 \pm 0,67^{\mathrm{a}}$ & $1,20 \pm 0,87^{\mathrm{b}}$ & $0,68 \pm 0,58^{\mathrm{a}}$ \\
FH & 38 & $1,30 \pm 0,88^{\mathrm{a}}$ & $0,16 \pm 0,09^{\mathrm{a}}$ & $2,55 \pm 1,21^{\mathrm{c}}$ \\
HHH & 25 & $1,27 \pm 0,63^{\mathrm{a}}$ & $1,92 \pm 0,49^{\mathrm{c}}$ & $3,69 \pm 1,32^{\mathrm{d}}$ \\
ÖNY & 20 & $1,05 \pm 0,69^{\mathrm{a}}$ & $0,75 \pm 0,55^{\mathrm{b}}$ & $4,81 \pm 0,99^{\mathrm{e}}$ \\
Rez & 18 & $1,48 \pm 0,82^{\mathrm{a}}$ & $1,83 \pm 0,65^{\mathrm{c}}$ & $8,39 \pm 1,14^{\mathrm{f}}$ \\
RH & 53 & $1,36 \pm 0,89^{\mathrm{a}}$ & $0,19 \pm 0,25^{\mathrm{a}}$ & $1,63 \pm 1,18^{\mathrm{b}}$ \\
\hline
\end{tabular}


nagyobb különbségek az egyes helyek mésztartalmában voltak, a 4D és a 7I erdőrészlet egy csoportba került, míg a többi mintaterület jól elkülönül egymástól, öt további csoportot alkotva. A többi talajparaméterben nem volt ilyen határozottan elkülönülő, szignifikáns különbség.

\section{Védett növényfajok termöhelyi jellemzöi}

A védett növényfajok termőhelyein mért termőréteg vastagság alapján nagyon átfedő csoportok alakultak ki (4. táblázat). Az Allium sphaerocephalon-nál tapasztaltuk átlagosan a legsekélyebb humuszos réteget, míg az Anthericum liliagonál volt a legmélyebb a humuszos réteg vastagsága (4. táblázat). Az Ephedra distachya, a Gypsophila arenaria, az Achillea ochroleuca, a Centaurea arenaria és a Stipa borystenica kevésbé volt érzékeny a humuszos réteg vastagságára, míg az Anthericum liliago-nak, a Centaurea sadleriana-nak, a Dianthus serotinusnak, az Iris arenaria-nak, az Iris variegata-nak és a Stipa pennata-nak szükebb volt az előfordulási tartománya (1. függelék 1 . ábra az online függelékben [OF]).

A felső réteg mésztartalma esetében két nagyobb és egy kisebb csoport különült el (4. táblázat). A növények többsége nem volt érzékeny a talaj felső rétegé-

4. táblázat: A védett növények előfordulását magyarázó talajtani tényezők átlagértékei és szórásai, minimum és maximum értékei a felső talajrétegben. (felső indexben az elvégzett Tukey-tesztek eredményei)

\begin{tabular}{|c|c|c|c|c|c|c|c|}
\hline \multirow{2}{*}{ 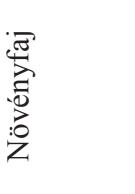 } & \multirow{2}{*}{ 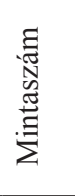 } & \multicolumn{2}{|c|}{$\begin{array}{l}\text { Termöréteg vastagsága } \\
\qquad(\mathrm{cm})\end{array}$} & \multicolumn{2}{|c|}{$\begin{array}{l}\text { Mésztartalom } \\
\text { (felső réteg) }\end{array}$} & \multicolumn{2}{|c|}{$\begin{array}{c}1-2 \mathrm{~mm} \\
\text { (felső réteg) }\end{array}$} \\
\hline & & átlag \pm szórás & $\begin{array}{c}\min - \\
\max \end{array}$ & átlag \pm szórás & $\begin{array}{c}\min - \\
\max \end{array}$ & átlag \pm szórás & $\begin{array}{c}\min - \\
\max \end{array}$ \\
\hline Ach och & 50 & $15,20 \pm 6,07^{\mathrm{abc}}$ & $5-30$ & $1,60 \pm 1,90^{\mathrm{ab}}$ & $0,2-8,7$ & $0,78 \pm 0,84^{\mathrm{abcd}}$ & $0,02-2,8$ \\
\hline Alk tin & 11 & $19,36 \pm 2,25^{\mathrm{bcd}}$ & $15-22$ & $3,18 \pm 1,54^{\mathrm{ab}}$ & $0,8-5,6$ & $0,36 \pm 0,71^{\mathrm{abc}}$ & $0,07-2$ \\
\hline All sph & 5 & $11,00 \pm 2,24^{\mathrm{d}}$ & $10-15$ & $1,00 \pm 1,20^{\mathrm{a}}$ & $0,2-3,1$ & $1,20 \pm 1,13^{\mathrm{bcd}}$ & $0,2-2,7$ \\
\hline Ant lil & 5 & $26,00 \pm 9,62^{\mathrm{a}}$ & $10-35$ & $2,60 \pm 1,08^{\mathrm{ab}}$ & $0,8-3,6$ & $1,20 \pm 0,65^{\mathrm{bcd}}$ & $0,5-2,3$ \\
\hline Cen are & 17 & $21,36 \pm 5,5^{\mathrm{cd}}$ & $10-30$ & $2,33 \pm 1,45^{\mathrm{ab}}$ & $0,2-4,8$ & $1,06 \pm 094^{\mathrm{abcd}}$ & $0,07-2,7$ \\
\hline Cen sad & 13 & $12,69 \pm 4,84^{\mathrm{ab}}$ & $10-25$ & $4,23 \pm 3,73^{b}$ & $0,2-9,4$ & $1,54 \pm 1,12^{\mathrm{cd}}$ & $0,05-3,4$ \\
\hline Diser & 14 & $17,50 \pm 2,34^{\mathrm{abc}}$ & $15-20$ & $3,00 \pm 1,15^{\mathrm{ab}}$ & $1,1-4,8$ & $0,16 \pm 0,06^{\mathrm{a}}$ & $0,07-0,3$ \\
\hline Eph dis & 107 & $16,56 \pm 6,28^{\mathrm{abc}}$ & $8-30$ & $1,64 \pm 1,38^{\mathrm{ab}}$ & $0,2-5,2$ & $0,73 \pm 0,88^{\mathrm{abcd}}$ & $0,02-3,4$ \\
\hline Fes wagi & 128 & $19,62 \pm 6,28^{\mathrm{bcd}}$ & $5-35$ & $2,20 \pm 1,58^{\mathrm{ab}}$ & $0,2-6,7$ & $0,70 \pm 0,80^{\text {abcd }}$ & $0,05-3,1$ \\
\hline Gyp are & 48 & $18,98 \pm 7,55^{\mathrm{abcd}}$ & $10-35$ & $4,21 \pm 2,76^{\mathrm{b}}$ & $0,2-10,2$ & $1,46 \pm 0,80^{\mathrm{cd}}$ & $0,1-3,1$ \\
\hline Iri aren & 30 & $12,77 \pm 4,76^{\mathrm{ab}}$ & $10-25$ & $3,14 \pm 3,84^{\mathrm{ab}}$ & $0,2-10,2$ & $1,07 \pm 0,86^{\mathrm{abcd}}$ & $0,05-2,6$ \\
\hline Iri vari & 5 & $12,00 \pm 2,73^{\mathrm{ab}}$ & $10-15$ & $9,00 \pm 0,86^{\mathrm{c}}$ & $8,1-10,2$ & $1,80 \pm 0,44^{\mathrm{d}}$ & $1,3-2,4$ \\
\hline Stip bor & 118 & $18,50 \pm 6,61^{\mathrm{abcd}}$ & $5-35$ & $3,21 \pm 2,29^{\mathrm{ab}}$ & $0,2-10,2$ & $0,84 \pm 0,86^{\mathrm{abcd}}$ & $0,05-3,4$ \\
\hline Sti pen & 15 & $23,00 \pm 4,55^{\mathrm{cd}}$ & $10-30$ & $1,33 \pm 0,9^{\mathrm{a}}$ & $0,4-3,6$ & $0,07 \pm 0,13^{\mathrm{ab}}$ & $0,1-0,6$ \\
\hline
\end{tabular}


nek mésztartalmára (átfedő csoportokat alkottak), ezeken a csoportokon belül az Allium sphaerocephalon és a Stipa pennata volt a legalacsonyabb mésztartalmú termőhelyeken, míg a Gypsophila arenaria és a Centaurea sadleriana a magasabb mésztartalmú termőhelyeken fordult elő. Külön csoportot alkotott, kiugróan magas mésztartalmú (átlag=9\%), szük előfordulási tartományú talajigényével az Iris variegata. A Centaurea arenaria, a Centaurea sadleriana, az Iris arenaria, a Gypsophila arenaria és a Stipa borysthenica különböző mésztartalmú termöhelyeken is előfordul. Az Allium sphaerocephalon és a Stipa pennata alacsony mésztartalom igényéhez különösen szük előfordulási tartomány párosul (1. függelék 2. ábra az online függelékben [OF]).

A felső réteg 1-2 mm közötti frakció aránya alapján négy átfedő csoport jött létre. A Dianthus serotinus olyan termőhelyeken fordult elö, ahol ez a frakció hiányzott, míg legnagyobb arányban az Iris variegata termőhelyein volt jelen (4. táblázat). Az 1-2 mm közötti frakció arányát tekintve az Allium sphaerocephalon, a Centaurea arenaria, a Centaurea sadleriana, a Gypsophila arenaria, az Iris arenaria és a Stipa borysthenica tág türésü, míg az Alkanna tinctoria, a Dianthus serotinus és a Stipa pennata sokkal szükebb és alacsony tartományban fordult elő (1. függelék 3. ábra az online függelékben $[\mathrm{OF}]$ ).

5. táblázat: A védett növények előfordulását magyarázó talajtani tényezők átlagértékei, szórásai, minimum és maximum értékei az alsó talajrétegben. (felső indexben az elvégzett Tukey-tesztek eredményei)

\begin{tabular}{|c|c|c|c|c|c|}
\hline \multirow{2}{*}{$\begin{array}{l}\text { त्ञ } \\
\overparen{D} \\
: 0 \\
: 0 \\
z\end{array}$} & \multirow{2}{*}{ 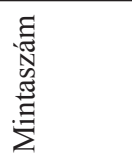 } & \multicolumn{2}{|c|}{$\begin{array}{l}\text { Mésztartalom } \\
\text { (alsó réteg) }\end{array}$} & \multicolumn{2}{|c|}{$\begin{array}{c}\text { 1-2 mm frakció aránya } \\
\text { (alsó réteg) }\end{array}$} \\
\hline & & átlag ${ }$ szórás & $\min -\max$ & átlag \pm szórás & $\min -\max$ \\
\hline Ach och & 50 & $3,86 \pm 3,50^{\mathrm{ab}}$ & $0,2-18,2$ & $0,53 \pm 0,54^{\mathrm{ab}}$ & $0,02-2,5$ \\
\hline Alk tin & 11 & $4,00 \pm 3,30^{\mathrm{ab}}$ & $0,8-10,9$ & $0,47 \pm 0,80^{\mathrm{ab}}$ & $0,05-2,7$ \\
\hline All sph & 5 & $2,00 \pm 1,20^{\mathrm{a}}$ & $0,4-3,0$ & $0,88 \pm 0,53^{\mathrm{abc}}$ & $0,1-1,3$ \\
\hline Ant lil & 5 & $10,60 \pm 5,95^{\mathrm{d}}$ & $1,7-16,1$ & $1,65 \pm 1,47^{\mathrm{cd}}$ & $0,2-3,4$ \\
\hline Cen are & 17 & $6,04 \pm 4,46^{\mathrm{abcd}}$ & $0,8-16,1$ & $1,09 \pm 0,53^{\mathrm{abc}}$ & $0,08-3,6$ \\
\hline Cen sad & 13 & $5,69 \pm 3,70^{\mathrm{abc}}$ & $1,5-11,3$ & $1,63 \pm 1,25^{\mathrm{cd}}$ & $0,1-3,8$ \\
\hline Diser & 14 & $2,79 \pm 1,47^{\mathrm{a}}$ & $0,8-6,5$ & $0,14 \pm 0,09^{\mathrm{a}}$ & $0,02-0,3$ \\
\hline Eph dis & 107 & $3,38 \pm 2,67^{\mathrm{ab}}$ & $0,4-18,2$ & $0,53 \pm 0,60^{\mathrm{ab}}$ & $0,02-3,0$ \\
\hline Fes wagi & 128 & $4,47 \pm 3,73^{\mathrm{ab}}$ & $0,2-18,2$ & $0,67 \pm 0,81^{\mathrm{abc}}$ & $0,02-3,6$ \\
\hline Gyp are & 48 & $7,50 \pm 4,29^{\mathrm{bcd}}$ & $0,2-16,1$ & $1,52 \pm 1,11^{\mathrm{bcd}}$ & $0,05,3,6$ \\
\hline Iri aren & 30 & $4,03 \pm 4,08^{\mathrm{ab}}$ & $0,2-13,8$ & $1,05 \pm 0,90^{\mathrm{abc}}$ & $0,1-3,1$ \\
\hline Iri vari & 5 & $10,20 \pm 2,25^{\mathrm{cd}}$ & $7,9-13,8$ & $2,25 \pm 0,34^{\mathrm{d}}$ & $1,9-2,7$ \\
\hline Stip bor & 118 & $5,74 \pm 3,53^{\mathrm{abc}}$ & $0,4-16,1$ & $0,85 \pm 0,93^{\mathrm{abc}}$ & $0,02-3,6$ \\
\hline Stipen & 15 & $1,73 \pm 1,04^{\mathrm{a}}$ & $0,6-4,2$ & $0,18 \pm 0,09^{\mathrm{a}}$ & $0,07-0,4$ \\
\hline
\end{tabular}


Az alsó rétegben mért mésztartalom alapján két nagyobb és két kisebb csoport különíthető el (5. táblázat). Az Anthericum liliago, a Centaurea arenaria a Festuca wagneri, a Gypsophila arenaria, az Iris arenaria és a Stipa borysthenica termőhelyeinek alsó rétegében a mésztartalom tág intervallumban változott, míg az Alkanna tinctoria, az Allium sphaerocephalon, a Dianthus serotinus, az Iris variegata és a Stipa pennata termőhelyei esetében ez a spektrum jóval szükebb volt (1. függelék 4. ábra az online függelékben [OF]).

Az alsó réteg 1-2 mm közötti frakciójának aránya alapján három nagyobb és egy kisebb csoport különült el (5. táblázat). A Centaurea sadleriana, a Gypsophila arenaria, az Iris arenaria és a Stipa borysthenica termőhelyei esetében mért eredmények tág spektrumot fedtek le, míg a Stipa pennata, az Allium sphaerocephalon és az Iris variegata esetében jóval szükebb ez a tartomány.

Az egyes védett fajok elterjedését meghatározó legfontosabb talajtani tényezők Az összes kvadrát adatain elvégezve a fökomponens analízist és az eredményeket két dimenzióban ábrázolva az egyes termőhelyekről származó minták láthatóan különböző mértékben tömörülnek (6. táblázat, 2. függelék 1. ábra az online függelékben $[\mathrm{OF}])$. A leginkább egy pontban lokalizált pontfelhő, azaz a vizsgált talajtani tényezők szerint leginkább homogén csoport a Felső-peszéri (honvédségi) területeken tapasztalható, ezzel szemben például az Ösnyíresnél és a Rácháznál felvett kvadrátok jelentősen diszperzebb képet mutatnak. Különösen szétszórt a Hármashatár-hegy pontfelhője, tehát vizsgálataink alapján ez mutatkozik a legheterogénebb élőhelynek (2. függelék 1 . ábra az online függelékben $[\mathrm{OF}]$ ).

A védett növényfajok jelenlétét leginkább meghatározó paraméterek alapján a kvadrátjainkban előforduló fajok termőhelyei közül a Gypsophila arenaria (3. függelék 1. ábra az online függelékben [OF]) és a Centaurea arenaria (3. függelék 2. ábra az online függelékben [OF]) előfordulásai diszperz elrendeződést mutatnak a vizsgált mintavételi egységek teljes spektrumán. Hasonlóképpen viselkedik

6. táblázat: A fökomponensek lineáris függése az eredetileg vizsgált változóktól, illetve az egyes fökomponensek által magyarázott varianciahányad.

\begin{tabular}{|c|c|c|c|c|c|}
\hline Változó & PC1 & $\mathrm{PC} 2$ & $\mathrm{PC} 3$ & PC4 & PC5 \\
\hline Termőréteg vastagsága & $-0,033$ & $-0,843$ & $-0,426$ & $-0,023$ & 0,326 \\
\hline Felső réteg mésztartalma & 0,484 & $-0,114$ & 0,637 & $-0,101$ & 0,580 \\
\hline $\begin{array}{c}1-2 \mathrm{~mm} \text { frakció aránya a felső } \\
\text { talajrétegben }\end{array}$ & 0,435 & 0,411 & $-0,560$ & 0,407 & 0,403 \\
\hline Alsó réteg mésztartalma & 0,524 & $-0,326$ & 0,143 & 0,527 & $-0,567$ \\
\hline $\begin{array}{c}\text { 1-2 mm frakció aránya az alsó } \\
\text { talajrétegben }\end{array}$ & 0,548 & 0,036 & $-0,281$ & $-0,739$ & $-0,271$ \\
\hline Magyarázott varianciahányad & 0,483 & 0,232 & 0,152 & 0,069 & 0,063 \\
\hline
\end{tabular}


az Ephedra distachya (3. függelék 3. ábra az online függelékben [OF]), a Festuca wagneri (3. függelék 4. ábra az online függelékben [OF]), az Achillea ochroleuca (3. függelék 5. ábra az online függelékben $[\mathrm{OF}]$ ) és a Stipa borysthenica (3. függelék 6. ábra az online függelékben [OF]), azonban esetükben megfigyelhető bizonyos mértékủ csoportosulás, továbbá a vizsgált fajok közül ide tartozhat még az Anthericum liliago (3. függelék 7. ábra az online függelékben [OF]) is, ez azonban a rendelkezésre álló előforulások alacsony számából eredően nem állapítható meg kellö bizonyossággal.

A Centaurea sadleriana (3. függelék 8. ábra az online függelékben [OF]) és az Iris arenaria (3. függelék 9. ábra az online függelékben [OF]) termőhelyei diszjunkt elrendeződést mutatnak, míg az Alkanna tinctoria-nál (3. függelék 10. ábra az online függelékben [OF]) és az Allium sphaerocephalon-nál (3. függelék 11. ábra az online függelékben [OF]) ugyan esetükben csak két pont különül el a többi előfordulást tartalmazó csoporttól, azonban az előfordulások alacsony száma miatt ezeknél csak feltételezhető a diszjunkt előfordulási mintázat.

Három olyan védett faj volt, a Dianthus serotinus (3. függelék 12. ábra az online függelékben [OF]), az Iris variegata (3. függelék 13. ábra az online függelékben $[\mathrm{OF}]$ ) és a Stipa pennata (3. függelék 14. ábra az online függelékben [OF]), ahol az előfordulások megközelítőleg egy pont körül koncentrálódtak.

\section{Értékelés}

Az általunk vizsgált mintavételi területek között kimutatott különbségek rámutatnak arra, hogy a fiziognómiai jellemzők és a fajkészlet (ezen belül is a domináns füfajok) alapján egységesen záródó homokpusztagyepnek tekinthető termőhelyek táji léptékben jelentősen eltérő termőhelyi feltételekkel jellemezhetők az általunk vizsgált paraméterek tekintetében. Mivel vizsgálataink elsődleges (nem bolygatott) talajú gyepterületekre irányultak, így a mező- és erdőgazdálkodási tevékenységekből eredő potenciális varianciát kizártuk. Ezek alapján arra a következtetésre jutottunk, hogy a táji szinten jelentkező különbségek valószínúleg más (nem antropogén) tényezőkkel (pl. a talajfejlődésre eddig rendelkezésre állt idő) magyarázhatók; erre azonban nem terjedt ki vizsgálatunk.

Eredményeink alapján kirajzolódtak a vizsgált védett növények termőhely preferenciái, így pl. az Ephedra distachya, a Festuca wagneri, a Stipa borysthenica a humuszos réteg vastagságát, a mésztartalmat és az 1-2 mm közötti talajfrakció arányát tekintve tágtürésü, míg az Alkanna tinctoria, a Gypsophila arenaria, az Iris arenaria és az Iris variegata sokkal szükebb spektrumú volt. 
A védett fajok előfordulását leginkább a mésztartalom határozta meg. Gyengén elkülönülő csoportokat lehetett képezni a humuszos réteg vastagsága és durva homok frakció (1-2 mm közötti talajfrakció) aránya (mindkét szint) alapján.

A mésztartalom szempontjából az Allium sphaerocephalon és a Stipa pennata szük tủrésủ és az alacsony mésztartalmú termőhelyeket preferálja. Ezen fajok esetében az ökológiai indikáció mutatószámai nem teljesen egységesek, de minden esetben alacsony mésztartalmú termőhelyre utalnak (4. függelék 1. táblázat az online függelékben $[\mathrm{OF}])$. Zólyomi szerint enyhén meszes talajon fordulnak elö (RZ-érték: 4), Soó szerint semleges-mészkedvelők (RS-érték: 4-5 ill. 4), Borhidi szerint mészkedvelők (RB-érték: 8). Az Iris variegata termőhelyei esetében tapasztaltuk a legmagasabb mésztartalmat a védett fajok közül, Zólyomi is a meszes termőhelyek növényének tartja (RZ-érték: 5), Borhidi viszont (RB-érték: 7) csak gyengén baziklin fajnak sorolja be, bár már ehhez a kategóriához is hozzáteszi, hogy erősen savanyú termőhelyen sohasem fordulnak elö. Borhidi szerint az Anthericum liliago, a Centaurea sadleriana és a Stipa borysthenica kivételével mindegyik, általunk vizsgált védett faj jobban mészkedvelő az Iris varigata-nál (4. függelék 1. táblázat az online függelékben $[\mathrm{OF}])$. Soó a fajt tág türésűnek (RS-érték: 2-4) és kevésbé mészigényesnek tartja, ezt a besorolást szintén nem támasztották alá a kapott eredmények. Ugyanakkor Soó a Stipa borysthenicát is tág türésü fajnak tüntette fel, ami az eredményeinkben is megmutatkozott.

A növényfajok termőhelyeinek vízellátottságát befolyásolja a talaj szemcseösszetétele, humusztartalma, mésztartalma és a humuszos réteg vastagsága (Stefanovits 1981). Az Iris variegata esetében volt a termőhely mésztartalma a legmagasabb a védett fajok között, a Borhidi-féle talajnedvesség indikátor száma is e faj esetében a legmagasabb (4. függelék 1. táblázat az online függelékben $[\mathrm{OF}]$ ). A védett fajok közül egyedül az Iris variegata WB-értéke 4, ami már a félszáraz termőhelyek növényeit jellemzi. A humuszos réteg vastagsága az Anthericum liliago esetében volt a legnagyobb, a vízellátottsággal kapcsolatos értékszámai pedig szintén magasak a többi fajhoz viszonyítva. A mintaterüleinken előforduló védett növényfajok közül a legalacsonyabb vízigényre utaló értékszámokkal (WZ-érték: 0, FS-érték: 1, WB-érték: 1) az Alkanna tinctoria és az Ephedra distachya rendekezik, termőhelyeiken viszonylag vékony termőréteget és alacsony humusztartalmat mértünk. A mutatók szerint az „extrém száraz” (WZ), ,igen száraz” (FS), termőhelyek növényei ezek, „erősen szárazságtürő növények gyakorta teljesen kiszáradó, vagy huzamosan szélsőségesen száraz termöhelyeken" (WB).

A védett fajok elterjedését legjobban magyarázó változóink alapján számított fökomponens analízis ábrája (2. függelék 1. ábra az online függelékben [OF]) jól szemlélteti a termőhelyeken belül megfigyelhető változatosságot és a fajok 
eloszlását (3. függelék ábrái az online függelékben [OF]) az edafikus tulajdonságok kombinációi által lehatárolt hipertérben. Az egyes magyarázó változók (edafikus tulajdonságok) fökomponensekbe sorolását a 6. táblázat foglalja össze. A Dianthus serotinus és a Stipa pennata előfordulásai szük tartományba és határozottan egy csoportba rendeződtek. Az Ephedra distachya, a Stipa borysthenica és a Gypsophila arenaria előfordulásai a rendelkezésre álló spektrum nagy részét lefedték és a optimum érték körüli csopotosulás is jóval kisebb mértékü volt.

\section{Következtetések}

Munkánk során meghatároztuk a Felső-kiskunsági záródó homokpusztagyepek védett fajainak edafikus termőhelyigényeit.

Bár az általunk vizsgált termőhelyek talajtani szempontból kevéssé tủnnek változatosnak, eredményeink kimutatták, hogy egyes növényfajok igen érzékenyen reagál(hat)nak a kismértékủ talajtani különbségekre is (mésztartalom, talaj levegőzöttsége, talaj humuszkészlete). Az élőhely reskonstrukció során ezen finom különbségeket is figyelembe kell venni (Critchley et al. 2002). Az eredmények felhasználhatók lesznek a parlagszukcessziót segítő aktív természetvédelmi kezelések (pl. rosszul terjedő fajok propagulumainak bevitele), illetve az élőhely-rekonstrukciók során. Az adott terület termőhelyi adottságaihoz igazodó fajkészlet meghatározásával, ilyen módon hozzájárulhatunk ezen munkák sikerességének növeléséhez.

Köszönetnyilvánitás - Köszönettel tartozunk a terepi mintavételezés és a laboratóriumi munka során segítséget nyújtóknak: Orbán Ildikónak, Pálfi Bencének, Vadász Jankának és Vadász-Besnyői Verának. Pacsai Bálintnak köszönjük az adatelemzések során nyújtott segítségét. A vizsgálatok terepi feltételeinek biztosításáért hálásak vagyunk a Kiskunsági Nemzeti Park Igazgatóságnak. A kutatás az Emberi Erőforrások Minisztériuma UNKP18-2 kódszámú Új Nemzeti Kiválóság Programjának támogatásával készült.

\section{Irodalomjegyzék}

Biró, M., Horváth, F., Révész, M., Molnár, Zs. \& Vajda, Z. (2011): Száraz homoki élőhelyek és átalalkulásuk a Duna-Tisza közén a 18. századtól napjainkig. - In: Rosalia 6. Természetvédelem és kutatás a Duna-Tisza közi homokhátságon. - Duna-Ipoly Nemzeti Park Igazgatóság, Budapest, pp. 383-421.

Critchley, C. N. R., Chambers, B. J., Fowbert, J. A., Sanderson, R. A., Bhogal, A. \& Rose, S. C. (2002): Association between lowland grassland plant communities and soil properties. - Biol. Conserv. 105: 199-215. https://dx.doi.org/10.1016/S0006-3207(01)00183-5 
Czóbel, Sz., Cserhalmi, D., Nagy, J., Szerdahelyi, T. \& Szirmai, O. (2007): Társulástan (Cönológia). - In: Tuba Z., Szerdahelyi T., Engloner A., Nagy J. (szerk.): Botanika III. - Nemzeti Tankönyvkiadó, Budapest, pp. 569-627.

Dövényi, Z. (szerk.) (2010): Magyarország kistájainak katasztere. Második, átdolgozott és bővített kiadás. Magyar Tudományos Akadémia, Budapest, pp. 406-409.

Fekete, G., Molnár, Zs., Kun, A., Virágh, K. \& Botta-Dukát, Z. (2002): Záródó homokpusztagyep a Duna-Tisza-közén: a Festuca wagneri gyepjei. - In: Salamon-Albert, É. (szerk.): Magyar botanikai kutatások az ezredfordulón. Tanulmányok Borhidi Attila 70. születésnapja tiszteletére. - PTE, Növénytani Tanszék, Pécs, pp. 381-411.

Gergely, A., Máté, A. \& Vidéki, R. (2008): Csepeli-sík. - In: Király, G., Molnár, Zs., Bölöni, J., Csiky, J., Vojtkó, A. (szerk.): Magyarország földrajzi kistájainak növényzete. - MTA ÖBKI, Vácrátót, 11. p.

Hargitai, L. (1988): A talaj szerves anyagának meghatározása és jellemzése. - In: Buzás, I. (szerk.): Talaj és agrokémiai vizsgálati módszerkönyv 2. A talajok fizikai-kémiai és kémiai vizsgálati módszerei. - Mezőgazdasági Kiadó, Budapest. pp. 151-173.

Horváth, F., Dobolyi, Z. K., Morschhauser, T., Lőkös, L., Karas, L. \& Szerdahelyi, T. (1995): Flóra adatbázis IV. 7. - MTA ÖBKI, Vácrátót, pp. 51-60.

Kecskeméty, L., Izsó, L. \& Könyves Tóth, E. (2011): Bevezetés az IBM SPSS Statistics programrendszerbe. - Artéria Stúdió Kft., Budapest

Máté, A. (2014): 6260 Pannon homoki gyepek. - In: Haraszthy, L. (szerk.): Natura 2000 fajok és élőhelyek Magyarországon. - Pro Vértes Közalapítvány, Csákvár, pp. 817-823.

Molnár, Zs., Király, G., Fekete, G., Aszalós, R., Barina, Z., Bartha, D., Biró, M., Borhidi, A., Bölöni, J., Csiky, J., Czúcz, B., Dancza, I., Dobor, L., Farkas, E., Farkas, S., Horváth, F., Kevey, B., Lőkös, L., Molnár, V. A., Magyari, E., Németh, Cs., Papp, B., Pinke, Gy., Schmidt, D., Schmotzer, A., Solt, A., Sümegi, P., Szmorad, F., Szurdoki, E., Tiborcz, V., Varga, Z. \& Vojtkó, A. (2018): Növényzet. - In: Kocsis, K. (föszerk.): Magyarország nemzeti atlasza: természeti környezet. Magyar Tudományos Akadémia, Csillagászati és Földtudományi Kutatóközpont, Földrajztudományi Intézet, Budapest, pp. 94-103.

Molnár, Zs., Varga, Z., Biró, M., Dénes, A., Fekete, G., Horváth, A., Kun, A., Ortmanné, Ajkai A. \& Takács, A. A. (2006): Dunai-Alföld. - In: Fekete, G., Varga, Z. (szerk.): Magyarország tájainak növényzete és állatvilága. - MTA Társadalomkutató Központ, Budapest, pp. 51-195.

Molnár, Zs. (szerk.) (2003): A Kiskunság száraz homoki növényzete. - Természetbúvár Alapítvány Kiadó, Kecskemét https://www.okologia.mta.hu/sites/default/files/homokkonyv teljes magyar. pdf

Stefanovits, P. (1981): Talajtan. 2. átdolgozott kiadás. - Mezőgazdasági Kiadó, Budapest, 380. p.

Vadász, Cs. (2015): Az inváziós növényfajok visszaszorításának tapasztalatai a Felső-kiskunsági Turjánvidéken. - In: Csiszár, Á., Korda, M. (szerk.): Özönnövények visszaszorításának gyakorlati tapasztalatai. Rosalia kézikönyvek. - Duna-Ipoly Nemzeti Park Igazgatóság, Budapest, pp. 181-188.

Várallyay, Gy. (1993): A talaj mechanikai összetételének vizsgálata. - In: Buzás I. (szerk): Talaj és agrokémiai vizsgálati módszerkönyv 1. A talaj fizikai, ásványtani és ásványtani vizsgálata. INDA 4231 Kiadó, Budapest, pp. 35-44.

Vidéki, R., Máté, A. \& Molnár, Zs. (2008): Kiskunsági-homokhát. - In: Király, G., Molnár, Zs., Bölöni, J., Csiky, J., Vojtkó, A. (szerk.): Magyarország földrajzi kistájainak növényzete. - MTA ÖBKI, Vácrátót, 19. p.

statisztikai elemzések: IBM Corp. Released 2012. IBM SPSS Statistics for Windows, Version 21.0. Armonk, NY: IBM Corp. 


\title{
Függelék:
}

A cikkhez tartozó online függelékek a folyóirat honlapján találhatók.

Függelék 1: A mintaterületeinken előforduló védett növényfajok termőhelyein mért különböző talajtani adatok boxplot ábrái.

Függelék 2: A különböző mintavételi helyeket összehasonlító, a védett növényfajok elterjedésében kulcsszerepet játszó talajtani paraméterek alapján számított fökomponens analízisének biplot ábrája.

Függelék 3: A vizsgált fajok előfordulásait a mintavételi helyekkel összehasonlító, a védett növényfajok elterjedésében eredményeink alapján kulcsszerepet játszó talajtani paraméterek alapján számított főkomponens analízisének biplot ábrája.

Függelék 4: A védett növényfajok vízháztartásra és talaigényre vonatkozó ökológiai mutatószámai.

\section{Soil characteristics of the protected plant species of closing sandsteppes in the Upper Kiskunság area}

\author{
Bence Fülöp ${ }^{1}$, László Nyári ${ }^{1}$, Márk Deák ${ }^{1}$, Annamária Balogh ${ }^{1}$, \\ Csaba Molnár ${ }^{1}$, Judit Bódis ${ }^{1}$, István Sisák ${ }^{2}$ and Csaba Vadász ${ }^{3}$ \\ ${ }^{1}$ University of Pannonia, Georgikon faculty, H-8360 Keszthely, Deák F. u. 16., Hungary \\ ${ }^{2}$ University of Szeged, Faculty of Agriculture, \\ H-6800 Hódmezövásárhely Andrássy út 15., Hungary \\ ${ }^{3}$ Kiskunság National Park, H-6000 Kecskemét, Liszt Ferenc u. 19., Hungary \\ E-mail:9112bence@gmail.com
}

In determining the species composition and abundance conditions of the vegetation in the sandy areas, the site characteristics have a major importance. The closing sand grasslands (Festucetum wagneri) are one of the endemic sand grasslands in the Pannonian biogeographical region, most of their characteristic species are protected by law. A good basis for getting to know the fine-scale patterns of the habitat type is to determine the habitat preferences of the species on primeval grasslands (primary, undisturbed grasslands).

Our study was carried out in the Upper Kiskunság area, where we investigated 208 quadrates, $50 \times 50 \mathrm{~cm}$ each. From the quadrates, a total of 416 soil samples were collected, by sampling the two top soil layers. We determined the lime and humus content of our soil samples, the particle size composition and colour measurements were also performed. In the statistical analysis we used analysis of variance and principal component analysis.

Our results revealed a fine but firmly distinct niche segregation according to the edaphic factors, and help us to select and reestablish site-specific species populations, adapted to edaphic conditions during future habitat restorations.

Keywords: Festucetum wagneri, edaphic factors, fine-scale patterns 